\title{
Memória e performance - dispositivos de captura e hibridismo entre arte e jornalismo cultural
}

Memory and performance - devices of capture and hybridism between art and cultural journalism

Carlos Alberto Franzoi ${ }^{1}$

Néri Pedroso ${ }^{2}$ 


\section{Resumo}

Registro de uma experiência, o presente artigo, proposto pelo Serviço Social do Comércio (Sesc) e pela Universidade do Estado de Santa Catarina (UDESC), se alinha a uma prática de jornalismo cultural preocupado com a construção mínima de memória de um projeto, no caso a Semana Performática, ocorrida entre 21 e 27 de setembro de 2015, em Florianópolis. Mapeamento de experimentos no campo da chamada arte da presença, o artigo reflete sobre a questão do tempo e da narrativa. Num primeiro momento descreve-se o evento, num segundo elenca os registros da agenda e, por fim, as considerações.

Palavras-chave: Corpo; performance; riso; ironia; paródia.

\section{Abstract}

Record of an experience, the present article, proposed by Serviço Social do Comércio (Sesc) and by Universidade do Estado de Santa Catarina (Udesc), is aligned to a practice of cultural journalism concerned with the minimal construction of the memory of an Project, in this case the Performance Week, that happened between September 21th and 27th, 2015, in Florianópolis. Mapping of experiments in field of the so-called art of presence, the article reflects about an issue of time and narrative. Initially, the event is described, then the records of the agenda are listed and, finally, the considerations.

Keywords: Writing; experience; memory; open work; performance. 
Aproximação entre a escrita de uma jornalista e um artista visual, o presente estudo, carrega o desejo de reter o vivido como um exercício de rememoração. Vasculha anotações de um presente que já é passado e de um passado que se mescla ao presente, numa fixação que se dá por meio da escritura.

Os recursos adotados são as lembranças, as anotações feitas durante e logo após o acompanhamento da agenda, em especial as apresentações de performances e uma performance ritual e, em outros momentos, na observação de fotografias, de documentos audiovisuais e das conversas analíticas sobre o que foi visto e pensado. Qual é o melhor modo de estabelecer uma narrativa sobre o passado em se tratando de um conjunto de trabalhos de difícil definição, reunidos sob uma agenda que se chama Semana Performática? Quais seriam os melhores dispositivos de captura dessas ações? Como abarcar a experiência, como entrecruzar dois olhares, como constituir memória a partir da escrita?

À luz de teóricos contemporâneos que pensam a questão da memória, da escritura, da palavra e da imagem, como Walter Benjamin, Henri Bergson, Aby Warburg, Jacques Derrida, entre outros, sabe-se que a memória não se faz apenas de lembranças, que ela oscila entre as imagens do passado, do imediato e de até projeções do futuro. Nem linear, nem informe, funciona como uma arquitetura que tem por base o ato de lembrar e esquecer, de interstícios entre o presente e o passado, entre o dito e o não dito.

O ato de expor, contar uma ação, pressupõe, portanto, o encadeamento de palavras e imagens formadas muitas vezes de modo anacrônico. A narração denota criação intelectual. Requer descrições, interpretações, consistência lógica, fundamentação empírica, montagem. "O arquivo não é uma questão de passado, é uma questão de futuro. O arquivo não trata do passado, ele trata do futuro", diz Derrida (2012, p.132). Outro filósofo, Georges Didi-Huberman (2011, p.61), também menciona esse encontro dos tempos como algo definitivo, "essa colisão de um presente ativo com seu passado reminiscente". Embaralhado, o tempo histórico conjuga-se, mistura anacronismo e contemporaneidade. Fragmentada, a memória não é estanque.

Híbrido, o presente trabalho aproxima um artista performático e uma jornalista num atravessamento temporal. Os registros das ações e a análise do momento presente ocorrem de modo individual, compartilhado e, ou então, de maneira diferenciada - um como observador (Néri Pedroso, a jornalista), outro como participante (Franzoi, artista performático), ou seja, dentro da ação. Ora a escrita assume um caráter descritivo e ora tende à análise mais crítica, embora sem a pretensão dos contornos de uma crítica especializada. A intenção das anotações e conversas, além da documentação e análise do assistido, é preservar contornos emocionais e imagéticos.

A Semana Performática se constituiu de uma ampla programação, desenvolvida em diferentes lugares de Florianópolis no período da manhã, tarde e noite com o objetivo "de refletir sobre o treinamento, a criação e pesquisa contemporânea em performance art, em seus imbricamentos com as diversas linguagens artísticas" 3 . Criada em 2012, a iniciativa do programa de extensão Laboratório de Performance; em 2015 teve a coordenação da professora Daiane Dordete, do Departamento de Artes Cêni-

${ }^{3}$ Portal UDESC - http://www.udesc.br 
cas (DAC), do Centro de Artes (CEART), da UDESC. Co-realização, envolvendo o programa de extensão Moinho - pensamento em movimento (DAC/CEART/UDESC), o programa de extensão Imagens Cênicas (DAC/CEART/UDESC), o Grupo de Pesquisa Poéticas Teatrais (DAC/CEART/UDESC) e o Sesc/SC. Aqui, a jornalista e o artista performático relatam o que ocorreu na Semana Performática de 2015.

Na parte matinal, a agenda prevê a oficina Da terra ao céu: a preparação vocal do performer, com Paula Noellia Cianfagna e Massimiliano Buldrini (Itália); Práticas teatrais de treinamento: wiewpoints e método Suzuki, com Fabiano Lodi (SP); Formação para danças com corpos grandes e pequenos, com Eryn Trudell (Canadá). Em horários e locais distintos, ocorreram seis performances - Sobre greens talks - segunda ação, do Erro Grupo (SC), Due latti dela campana, de Teffa Polidoro (SC), Constelações, de Maíra Wiener e Alyssa Tessari (SC), Entrenós, de Franzoi (SC), Sem Cabimento, do coletivo Mapas e Hipertextos (SC), Pequeno manual de inapropriações, de Daiane Dordete (SC), uma performance ritual, Meditação sonora, do Cantos de Gaia (SC), e Fogo sonoro, de Isabella Irlandini e Luigi Irlandini (SC).

O compromisso reflexivo se dá por meio da Jornada de Pesquisa, com a palestra Ritos urbanos e arquiteturas da performance, com Milton Andrade (SC) e Políticas da identidade na performance mexicana, com Antonio Prieto (México), além das mesas-redondas Experiências de compra e venda do Erro Grupo no mercado de arte, com o Erro Grupo, Práticas da atenção: deslocamentos orientais, com Fabiano Lodi, Débora Zamarioli, Vicente Mahfuz, Jacqueline Sodré e Maria Brígida de Miranda (mediadora); Práticas de atenção: o cultivo de si/outro, com Francisco Gaspar, Milene Duenha, Priscila Padilha, Bianca Scliar e Sandra Meyer (mediadora) e Voz e $(m)$ performance, com Janaína Martins, Isabella Irlandini, Massimiliano Buldrini, Paula Noelia Cianfagna e Daiane Dordete (mediadora).

No registro das performances, a jornalista assume a autoria de Sobre greens talks - segunda ação. O texto sobre Due latti dela campana é feito de modo conjunto, logo após a apresentação. Escrito com lápis, num bloco de anotações, une dois pensamentos. Constelações leva a assinatura do artista. Por ser um trabalho de Franzoi, Entrenós, ganha escritura da jornalista, assim como Sem cabimento. Pequeno manual de inapropriações e Fogo sonoro documentam-se por meio do olhar do artista e, por fim, a performance ritual, Meditação sonora, se desdobra em dois textos, o da jornalista como observadora e o do artista participando do ritual. Curioso que, ao viverem de modo diferenciado a proposta do grupo Cantos de Gaia, ambos saem com a mesma interrogação: isso é performance?

Ao conceituar performance, Liliana Coutinho, no texto De que falamos quando falamos de performance? busca uma definição pela negativa:

A performance seria aqui aquilo que não é: o que não é teatro, não é pintura, não é dança, não é escultura... Estaria nos intervalos de tudo isso que é, nos interstícios da representação, seria esse espaço negativo no qual também já nos falaram a propósito da pintura abstrata e dos seus ecos metafísicos de uma presença que se define pela ausência (Coutinho, 2008, p. 9).

Tal definição abre para as múltiplas possibilidades de expansão do termo performance e seu desdobramento de linguagens visuais, por meio de pontos de contato 
com a arte conceitual, leva em conta os procedimentos interdisciplinares, de contaminações com a dança, música, poesia e teatro. $O$ entrecruzamento se estabelece como um evento performático e busca a utilização do corpo enquanto forma constitutiva essencial da obra.

Segundo Regina Melim, no livro Performance nas artes visuais:

\begin{abstract}
Desde as vanguardas europeias, já se esboçavam ações performáticas que objetivavam rupturas, como as que ocorreram no futurismo, no construtivismo russo, no dadaísmo, no surrealismo e na Bauhaus. Contudo, foi a partir do segundo pós-guerra que tais ações se tornaram mais frequentes, assim como suas denominações: happening, Fluxus, aktion, ritual, demonstration, direct art, destruction art, event art, dé-collage, body art, entre outras tantas designações, creditadas, grande parte das vezes, ao processo de um único artista ou de um grupo. Todavia, a partir dos anos 70, não obstante as diferenças estilísticas e ideológicas que possuíam, acompanhadas ainda dos protestos de muitos artistas das artes visuais, todas essas denominações foram agrupadas sobre a terminologia única de performance art (Melim, 2008, p. 10).
\end{abstract}

O que tem em comum entre as denominações, citadas por Melim, é que todas valorizam a alteração do lugar da obra e suas situações instáveis e incorporam a criação e a vivência como elementos interdependentes. Isso leva o performer a uma condição inventiva e em processo que integra nas suas produções o cotidiano, suas ações e seus objetos, incorporando-os como arte, os denominados rituais performáticos.

Stiles acrescenta que em cada performance sujeitos e objetos das ações estão interligados e comprometidos entre si, são como comissuras. Inseparáveis, suas qualidades e seus significados estão expressos nas conexões que existem entre ambos. Os objetos contêm os traços da ação e, longe de serem apenas estímulos para a memória, encorajamento para que esta se torne presente e real, podem se apresentar como suas expansões (Melim, 2008, p. 38 e 39).

Portanto, a performance se faz presente nos procedimentos performativos a partir do conceito de participação e compartilhamento no qual o espectador é inserido na obra-proposição e lançado a categoria de coautor. Isso possibilita novas formas de comunicação e da estrutura relacional e altera a noção de espaço de performação.

\title{
Escritura performática, múltiplos sentidos
}

Poderosa ferramenta de contenção de memória, a escrita guarda mistérios e grava impressões corpóreas, táteis, sonoras e visuais. Carregadas de múltiplos sentidos e emoções, mescla o passado ao presente, como forma de construção e de desconstrução simbólica. A seguir as impressões retidas nos embates do tempo e do espaço pelos dispositivos de captura e hibridismo entre arte e jornalismo cultural, aqui entendido como especialização da atividade jornalística voltada para o âmbito da cultura, com produção de textos que estimulam análises e reflexões sobre eventos na área de teatro, artes visuais, cinema, literatura e música. 


\section{Incógnitas do caminho}

Néri Pedroso

Sobre greens talks - segunda ação $\mid 21$ maio 2015, 14h - praça Getúlio Vargas, centro de Florianópolis | Concepção: Erro Grupo (SC) | Performers: Luiz Henrique Cudo, Pedro Bennaton e Sarah Ferreira | Sinopse: http://labperformance. wixsite.com/labperformance

Tudo começa ao meio-dia na praça Getúlio Vargas, uma das mais belas de Florianópolis, com um acervo de árvores majestosas, chão batido, sensação de terra e areia nos pés, ela convida ao passeio. Convicções, práticas e dizeres ficam em suspenso, uma deriva na turbulência típica do horário, quando muitos saem dos escritórios para o almoço e, depois, deixam-se ficar em breve descanso no meio da atípica paisagem, na qual é possível ouvir o canto dos pássaros.

A ação envolve três atores, dois homens e uma mulher. Dois carrinhos de jardim, um deles acondiciona terra preta, adubo da melhor qualidade. No outro, um monte de moedas e algumas cédulas de dinheiro. Uma pá, uma enxada e um pequeno regador de cor verde compõem o arsenal desses "trabalhadores". O calendário assinala o Dia da Árvores, data ignorada pela maioria dos passantes.

A ação se inicia pela força masculina, a partir do gesto da pá na terra. Sem titubear, másculo e firme, um dos atores primeiro retira a grama do jardim, a meta, logo se percebe, é abrir um buraco. Em silêncio, com movimentos precisos revolve, escava, logo faz aparecer uma terra vermelha, com pedregulhos, árida. Em silêncio, o outro, ao lado do carrinho cheio de terra escura, observa a força do corpo que se move feito uma máquina. Nada a ser dito ali, a não ser contemplar a ação despercebida pela maioria, inclusive os dois policiais militares que pararam na praça e conversam alheios ao que ocorre ao seu redor.

Ela, ágil leva o seu carrinho de dinheiro de um lado para o outro, rápida em busca de conexão humana. "O senhor poderia fazer uma doação para a ajudar a investir nesta praça", pergunta impositiva. "Estamos fazendo uma campanha para a população adotar um espaço urbano." Pede: "Uma ajuda, pode ser qualquer coisa, uma moeda, mesmo que seja de R\$ 0,5". E, melhor, dando, pode dizer o que acha necessário, o que quer para a praça. Mais plantas, drenar, não colocar concreto, mais flores, mais bancos. O tom de voz é tão afirmativo que logo os apressados param e mexem nos bolsos em busca de um dinheiro, as mulheres abrem as sacolas; os homens, suas carteiras. Não conseguem escapar, vítimas da curiosidade e da crença que emana da convocatória: "Estamos fazendo uma campanha com a população, o senhor poderia fazer uma doação?". Poucos são os que evitam, fogem do contato sem falar nada.

Aline Jordão, 26 anos, Tatiany Assis, 30, e Cleuzi Maria da Luz, 30, aproveitam a pausa para o almoço, estão sentadas lado a lado no degrau da escada, bem próximas do local onde se cava o buraco. Convicta, a mulher vai interpelando quase todos os que passam, quer estejam sozinhos, acompanhados, homens, mulheres, jovens, a escolha é aleatória. Um carrinho de mão com dinheiro parece não causar estranhamento. Até os mais ensimesmados, suspendem a caminhada, se põem em escuta atenta e logo buscam nos seus pertences suas moedinhas. Poucos parecem surpre- 
sos, poucos demonstram incômodo, outros se explicam porque não irão contribuir "para adotar um espaço urbano": "Só tenho R\$ 10 no bolso", "saí sem dinheiro hoje", "estou indo ao banco, só tenho cartão".

[...] cremos nas palavras e nelas cremos porque cremos em nossos olhos: cremos que as coisas e os outros existem porque os vemos e que os vemos porque existem. Somos, pois, espontaneamente realistas. Ilusões e alucinações, longe de destruírem nossa crença na existência do mundo em si, reforçam o que Mearly-Ponty chamava de nossa fé perceptiva, porque a ilusão carrega a promessa de nossa fé perceptiva, porque a ilusão carrega a promessa de uma visão verdadeira que corrigiria a ilusória, desde que corrijamos nosso ponto de vista, pois temos consciência da ilusão e da decepção apenas quando já substituímos uma evidência por outra (Chauí, 1988, p.32).

Aline, Tatiany e Cleuzi não percebem direito o que ocorre perto delas. Mesmo que não tenham contribuído, envolvem-se com o assunto, pensam em soluções para a praça, quem sabe mobilizar os dois colégios próximos, eles poderiam quem sabe adotá-la, envolvendo os alunos em algumas ações? Encerrados os pedidos de doação, a condutora do carrinho aproxima-se dos dois homens calados, à espera, ao lado da pequena cova, agora já concluída. Ela derrama o montante no buraco, moedas e cédulas contrastam com a terra avermelhada. Logo uma pá de terra preta, adubo fértil é jogado, seguida de outra e outra, sucessivas camadas. O silêncio potencializa o enterro dos investimentos da população. Ação pictórica, rito, desvelamento. Por fim, o "túmulo" é regado pela mulher, que faz a tarefa sem pressa, com extremo cuidado. O sepultamento encerra, recolhem-se as ferramentas e partem os três para a avenida Hercílio Luz.

Ali tudo se repete. Dona Rute, obrigada, a senhora acabou de adotar um espaço urbano. Desculpe ser só um pouquinho. Que nada, significa e muito senhor! O que faremos com esse dinheiro? Vamos investir aqui neste espaço urbano. "Falta polícia, segurança para as mulheres, a Hercílio Luz não está segura."

"Tem que investir no teatro", pedem os quatro integrantes da Cia. Teatral Pantomina que, vestidos com camisetas iguais da companhia, interrompem uma reunião realizada numa das mesas instaladas ao longo da avenida para contribuir com uma moedinha. "Gosto da ideia", diz um outro colaborador.

Silêncio, a pá, a grama, movimentos precisos, revolve, escava, mexe, arruma, a busca da simetria. A cova é feita ao lado de uma banca de revista. A terra urbana revela-se, tem cheiro.

Dali para a praça XV de Novembro, no centro histórico de Florianópolis, que também ganha uma cova para o dinheiro. Os senhores de uma das mesas de dominó querem muitas coisas: que derrubem aquele prédio ao lado, que façam um banheiro. O senhor tem alguma contribuição, porque para construir um banheiro sai caro. Queremos investir nos aparelhos urbanos da cidade para a população usufruir. "Sei que estou com pressa, mas sei que vocês vão fazer o melhor." Se quiserem saber o que vamos fazer com esse dinheiro é só acompanhar o nosso trabalho.

"Ah, eu vou ali cavoucar depois!", diz a idosa que vendo a doação dos homens do dominó, alguns passos adiante, próximo à célebre figueira percebe os dois homens e a mulher em silêncio, concentrados no enterro do dinheiro. Incrédula, ar- 
regala os olhos, quer entender melhor o que vê, mas a seguir desvia o foco, segue devagar de volta às sofreguidões humanas. "Pode jogar um imã aí dentro?", indaga outro jogador, agora um integrante do ponto de dominó que fica em frente ao desaparecido Senadinho, na rua Felipe Schmidt. "E onde é o espaço urbano", pergunta alguém com desconfiança depois que a mulher afasta-se com o carrinho. "Ah, esses aí são aqueles, foram eles que fizeram aquela parada esses dias à noite, lembra?". Obrigada gente, vocês acabaram de adotar o espaço urbano.

A ação transcorre até às 13 h47, no largo da Alfândega. Quando termina de regar a terra, a mulher bate palmas, ao que é acompanhada pelos espectadores um pouco confusos, sem a exata compreensão do que ocorreu ali. A ressonância da performance se estenderá, muitos levarão consigo o mistério e as perguntas.

- $E$, se depois, eles levarem o dinheiro, pergunta a jovem preocupada.

\section{Interstícios do vazio}

Néri Pedroso e Franzoi

Due latti della campana 21 maio 2015, 20h30, Laboratório 1, Ceart/Udesc | Concepção: Tefa Polidoro (RS) | Performer: Tefa Polidoro e Márcio Ramos | Sinopse: http://labperformance.wixsite.com/labperformance

Um recorte de um trabalho em processo, com duração de 20 minutos, coloca em cena uma atriz e um ator que dançam num espaço cênico em que duas cadeiras de madeira, instaladas de costas para o público, estão encobertas por um tecido bordado de flores em relevo. Antes da entrada na sala, os espectadores são informados de que a história do trabalho está baseada na misteriosa vida da tataravó, uma imigrante italiana que chegou ao Rio Grande do Sul no final do século XIX, que foi rejeitada pela família por não ter uma conduta adequada aos padrões da época. Pelo silêncio e abafamento, o protagonismo dessa mulher se fez na distância geográfica e temporal entre duas existências, a da tataravó e da tataraneta.

Teffa Polidoro faz um mergulho contra o tempo e a invisibilidade, tenta abarcar as dificuldades e as alegrias de uma mulher que ela não conheceu, "mesmo não contando nada, parece que vi toda a vida dela". Por meio da música e da dança, com falas, sem recorrer à linearidade, cria-se uma leitura sobre essa vida em confronto com o rigor paterno. "Estou grávida do Bruno pai... Ou do Pedro", grita uma mulher em pânico.

No corpo e na voz, os desdobramentos de uma memória fragmentada. "Não tem como não dizer que eu romantizo", admite a atriz/bailarina na conversa que se dá no término da apresentação. O olhar amoroso que retira uma pessoa de um passado nebuloso não é o problema da performance, mas sim as desconexões que se estabelecem na costura entre música, cenário, roteiro, composição coreográfica.

A trilha sonora provoca uma confusão já no início, porque identificada com sons afros, algo que assume o mesmo contorno nos movimentos que se aproximam ao gestual dos terreiros. Com relação ao cenário, a primeira pergunta: por que o tecido? E por que esconder as cadeiras? Aparentemente para encobrir a troca de figurino no desenrolar do trabalho. O encobrimento num espetáculo que pensa a revelação? 
No teatro contemporâneo o corpo cênico é expandido e a coxia pode integrar o espetáculo. O invisível torna-se visível em ações distintas, como a troca de figurino ou de cenário. A quebra da chamada quarta parede pode ser um dos caminhos para a aproximação com o público. O teatro de arena coloca o espectador como um coparticipante e possibilita modos diferenciados de ver e, portanto, múltiplas leituras.

A direção deveria apostar mais na plasticidade e no imagético do espetáculo, um exemplo claro é quando a atriz surge com um tecido que encobre o rosto, sugerindo uma máscara com traços cubistas que remetem ao Picasso e suas mulheres de Avignon. $O$ contraste se faz com a moldura dos longos cabelos avermelhados no tecido branco. Lindo!

A questão plástica deve apostar numa unidade, a começar pelo desenho e exploração do espaço cênico. A desmontagem do figurino poderia ocorrer de modo visível, evidenciando os aspectos pictóricos contidos na proposta. Teffa não presta atenção, parece não saber que a memória se constrói de modo fragmentado e que o afetivo não inviabiliza a operação historiográfica. O excesso de ideias é avassalador na narrativa que se tenta construir. Mais do que ressignificar uma vida, precisa-se pensar a arte como imagem dialética ou como construção de imagens.

\section{Diálogos corpóreos celestiais}

Franzoi

Constelaç̃̃es $\mid 24$ maio 2015, 13h, hall do bloco amarelo, Ceart/Udesc | Concepção: Alyssa Tessari e Maíra Wiener (SC) | Performers: Alyssa Tessari, Benedikt Mensing, Lucas Dalbem, Maíra Wiener e Tuany Fagundes | Sinopse: http://labperformance.wixsite.com/labperformance

Às 13 horas, cinco jovens iniciam a performance Constelações. O figurino unissex, na cor preta, é composto de bustiê, calção, botinas e coque. Essa composição abre para o conceito de gênero no qual cada indivíduo pode construir sua própria identidade. Os elementos de cena: um sino, duas tesouras, seis canetões na cor preta, um rolo de fita adesiva preta e um fio de lã vermelho colocados sobre uma mesa; um manual de instruções e uma lupa sobre um suporte para partitura musical.

No manual de instruções:

IMPORTANTE: A palavra de segurança dos performers é "não". Se algum deles usar essa palavra, pare imediatamente o que está fazendo. É proibido mexer nas roupas dos performers. INSTRUÇÕES: Escolha um dos materiais expostos na mesa próxima ao manual. Utilize: a) canetas para os corpos dos performers; b) o barbante para linhas no espaço; c) a fita isolante para pontos no espaço. Ligue pontos: na pele de um dos performers (com as canetas); nos corpos de dois (ou mais) performers diferentes (utilizando barbante e/ou fita isolante); no espaço (usando b) $+c$ ); entre um performer e o espaço $(\mathrm{com} b)+c$ ). Faça um novo ponto no espaço com fita isolante e conecte com outro que já existe no espaço ou no corpo de algum performer. Altere relações no espaço, mudando posições ou conexões entre performers, entre um performer e o espaço ${ }^{4}$.

${ }^{4}$ Retirado do objeto cênico Manual de Instruções. 
No rodapé da folha, corpo de letra pequena, para que o leitor necessite da lupa, o alerta: Não toque o sino.

Cinco performers, identificados aqui como: performer um, dois, três, quatro e cinco, de acordo com o sentido horário que cada um se posiciona no círculo formado. Silêncio. A luz externa adentra no hall. Um pássaro quebra o silêncio com seus chamados. O público transita pelo espaço. Alguns lançam o olhar e continuam seu percurso, outros passam apressados.

O fotógrafo observa a cena, lê o manual de instruções, busca ângulos. Pessoas sentadas nos bancos laterais apreciam. Outras se aproximam e leem as instruções. A primeira pessoa, após a leitura, pega a tesoura, corta pedaços da fita adesiva preta e um pedaço do fio que, logo, amarra no cotovelo direito do performer um, nas costas do performer quatro e na mão do performer três, unindo-os.

Muitos circulam e observam sem interferir. Vozes na cantina e murmúrio do público. A pessoa que iniciou a ação de atar os fios pega um canetão preto, desenha um traço no peito do performer dois, uma cruz no braço esquerdo do performer três, um círculo no peito do performer quatro e um triângulo no pescoço do performer cinco.

O canetão é entregue a alguém que observa atentamente a cena e, depois, escreve Oi na omoplata esquerda do performer dois. Outra pessoa para, com o olhar curioso, lê as instruções por uns segundos, vai até o performer cinco e toca o seu bustiê. O performer cinco diz: Não! A pessoa para e se retira.

Mais pessoas leem as instruções, observam por um tempo, fotografam e transitam pelo espaço. Os performers começam uma movimentação a partir das tensões provocadas pelos fios nos corpos. Uma pessoa ata as costas do performer dois ao braço direito do performer cinco. O performer dois gira o corpo e dá um passo, o que provoca micro ações nos outros.

Alguém se aproxima do performer dois e oferece um leão de pelúcia. O performer um lança um olhar para o objeto e estabelece um diálogo corporal que provoca deslocamentos na tentativa de se aproximar do brinquedo. Performer dois afasta o objeto, provoca movimentos coletivos em função dos fios atados e o lança para uma pessoa que os observa desde o início. Aqui se percebe a existência de três auxiliares/ cuidadores.

Uma pessoa ata o peito do performer três com o ombro direito do performer cinco. Outra une a perna direita do performer um às costas do performer quatro. Agora, todos estão conectados. Forma-se aí a primeira constelação.

Os performers começam a se mover lentamente com olhar fixo uns nos outros e com cuidado para não desatar a trama. Uma pessoa escreve nas costas do performer dois: TOQUE O SINO! E outra escreve a mesma frase nas costas do performer três. Após alguns segundos, uma cuidadora toca o sino. Imediatamente os performers relaxam, desatam os fios, as fitas adesivas, retornam à posição circular e trocam de posições. A sequência fica: performer um, dois, quatro, três e cinco.

Esse jogo cênico, entre performers e público, se repete por 19 batidas do sino, se modula e altera conforme o tempo se expande. Os posicionamentos mudam a cada nova badalada, provocam ações e reações entre os agentes da cena que permitem, tanto performers quanto público, se transformarem em coautores. $O$ conceito de obra aberta se faz presente por meio dessa performatividade e das novas conste- 
lações que se formam a cada ciclo.

No decorrer dos ciclos, há momentos de maior ou menor conexão do púbico, que perde a timidez e interage de diferentes formas: ligam os corpos dos performers por meio dos fios; expandem a constelação para o espaço arquitetônico; conduzem e posicionam os performers no espaço; desenham e escrevem nos corpos dos performers: NÃO TOQUE O SINO - VIVA O POVO GUARANI! AVATÉ - FALA COMIGO LIBERTE MEU CORPO DA SUA DOENÇA - ME DÊ UM ABRAÇO.

Os performers expandem seu campo de presença quando: permitem o contato entre seus corpos; emitem sons com a voz (cada performer produz um som, repetido continuamente: ouououou, miau-miau, auau-auau, iiii-iii, ahahah-ahahah. Performer dois grita: Chega! Performer quatro: Ai!); fazem caretas, gestos de sim e não com a cabeça; riem uns dos outros e do público; interagem corporalmente com o espaço arquitetônico; encaram o público com expressão forte; dialogam com os objetos do espaço; falam: hoje o suco do RU estava quente e era de laranja; cantam os parabéns.

Aparecem quebras desse ciclo quando: o performer dois levanta a mão direita e chama por Renata, o nome da auxiliar que toca o sino e anuncia a passagem do tempo: duas horas, na sexta badalada - três horas, na décima quinta - quatro horas, na décima oitava; os três cuidadores distribuem varas brancas aos performers que passam a interagir com o objeto; os performers não voltam a posição inicial do círculo após o sétimo e décimo badalo; o performer cinco tira as botinas após a décima segunda badalada (não há razão para tal ato, a não ser que tenha sido por desconforto, já que o figurino, visualmente plástico, não se sustenta na praticidade); o performer cinco anuncia as instruções e os outros começam a contar segredos.

Às 16h55, Renata toca o sino pela décima nona vez. Silêncio. O performer cinco pega o sino, corre, sobe a escada e desaparece. Retorna após algum tempo e, sem o sino, se deita no piso. Os performers um, dois e três vão até a mesa, depois se postam diante dos performers quatro e cinco que estão deitados no piso. Os dois levantam. Os cinco performers congelam. Silêncio. Transcorrem alguns segundos. Descongelam e começam a recolher todo o cenário com a ajuda dos cuidadores. O público bate palmas. Fim!

Sendo constelações, um grupo de estrelas em uma região delimitada do céu que permite o ser humano se deslocar de um ponto ao outro pela superfície do planeta, talvez possamos fazer uma analogia com os elementos apresentados na performance e as presenças e não presenças dos performers. O hall do bloco amarelo do CEART seria o espaço celeste; os performers, as estrelas; o fio, os pontos de ligação energética entre os corpos estrelares; as escritas e os desenhos, o diálogo no espaço-tempo entre os corpos celestiais.

\section{"Monstro" de nós}

Néri Pedroso

Entrenós | 25 maio 2015, 19h, hall do Teatro Sesc Prainha | Concepção e performer: Franzoi (SC) | Sinopse: http://labperformance.wixsite.com/labperformance 
A sala de recepção do Teatro Sesc Prainha é transformada em espaço cênico. Vestido de branco, o artista vem da rua ao encontro do público, composto por pessoas sentadas, a maioria em pé. Algumas custam a perceber o início da ação e seguem a conversa em voz alta. O corpo envolvo em um volume de nós, cerca de 70 quilos em tecido vermelho, cria uma imagem potente. Devagar, passo a passo, com rosto, braços, torso e barriga encobertos, o homem escultura tem dificuldade nos seus movimentos. Só os pés aparecem por inteiro.

Local de passagem, a sala contempla três entradas, a de acesso propriamente dito, a porta do elevador e outra para a biblioteca do Sesc, de onde saem frequentadores. A circulação de pessoas alheias à performance cria um estilhaço dentro do trabalho. Desatentos, esses passantes não sabem bem o que fazer quando se deparam com o que uma menininha, saída do elevador com a mãe e o irmão, define como "monstro". Assusta-se, chora e sem reservas compartilha o medo. O menino, quase do mesmo tamanho, ri - não se sabe se da cena, da irmã ou do próprio susto. Outro, um adulto, ao sair da biblioteca, surpreso, estaca. Diante do inverossímil, suspende o ritmo corporal como se subitamente tivesse sido congelado. O homem, talvez já indo para casa, está ali, agora, imóvel, na cena, em frente ao "monstro" que se move lentamente. Numa brecha, depois de alguns segundos que parecem uma eternidade, ele se liberta, retira-se, escapa do constrangimento.

O performer, então, debate-se com os nós, também tenta escapar daquilo que o tortura, o excesso de peso, os nós em torno do corpo. Mexe-se, respira, sua, debate-se. Aos poucos, desfaz os nós, um a um. No chão, eles compõem três volumes em separado que o artista logo trata de organizar. Vagarosamente, primeiro estabelece uma linha descontínua; depois, busca arquitetar com sofreguidão pequenas esculturas que remetem à figuração humana, difícil tarefa, luta contra a implacável lei da gravidade. Na disciplina e persistência, finalmente a imagem se constrói e ali fica - potente, agora como objeto artístico. Por fim, extenuado, arrasta-se no chão, cria linhas e curvas imaginárias, o corpo como um pêndulo hipoteticamente capaz de medir o tempo e o espaço.

\section{Irrupção do apocalíptico}

Néri Pedroso

Sem cabimento $\mid 25$ maio 2015, 20h, Teatro Sesc Prainha | Concepção: Coletivo Mapas e Hipertextos (SC) | Performers: Cecília Lauritzen, Diana Gilardenghi, Diana Piazza, Milene Duenha, Paloma Bianchi, Raquel Purper | Sinopse: http:// labperformance.wixsite.com/labperformance

Seis mulheres sentadas num banco, uma ao lado da outra. Sérias e compenetradas. O figurino alcança uma unidade nas cores e em blusas cavadas de alças leves, saias, shorts, preto, cinza, azul, bordô. Cada uma delas segura com a mão esquerda um taco vermelho, algo que lembra um cabo de vassoura. Com ele, compõem uma coreografia que flexiona o corpo sem o rompimento da postura original. A mão e o objeto delineiam o movimento das performers sentadas. O corpo move-se ora para a esquerda ora à direita, tudo em simetria, uma composição sem invariabilidade. Num certo momento, levantam a mão direita - deslocamento e gesto que remete a um 
pedido de socorro, indeterminado apelo.

Ao levantar, ocupam o espaço delimitado lateralmente por duas arquibancadas lotadas por uma atenta plateia. Em silêncio e passos lentos, lado a lado, de costas ou de frente, corpos que se entrecruzam, se interceptam, desenham o espaço cênico. Num segundo momento, sentam-se de novo no banco, no mesmo alinhamento. De repente, de modo quase invisível, cada uma delas tem uma calcinha na cabeça, o fundilho no nariz - máscara mortuária contemporânea.

De volta à pista, as bailarinas compõem o que se chama "ação modular do elástico" em que se submetem ao improviso, ao jogo imposto por tiras de plástico largas e fortes, numa composição em que o elemento material, conectado ao corpo, funciona quase como um personagem dentro do contexto. Todas usam uma venda nos olhos, artifício que amplia a instabilidade. À mercê de uma força invisível, se deslocam, enfrentam tensões, resistências, o imprevisível, o risco. Emperramento e fluidez, quedas, pausas, avanços, desistências, recuos. Disso, para outra composição que hibridiza dança e escrita com a mão esquerda. Público dividido entre destros e canhotos, cartazes com frases desconexas ou não, encharcadas de cotidiano e política - textos cicatrizes: "Mãe, eu sou da direita ou da esquerda?", "Tortura somente na hora certa", "Intervenção constitucional em Cristo".

E isso é o quê? Dança, performance, espetáculo, pura provocação, pensamento? Tudo ao mesmo tempo agora, como diz o poeta. Isso? São corpos marcados por dissonâncias, sem o compromisso do acerto. Bocas espumantes de tanta afronta, corpos de confusão que não temem o fracasso, que ajustam fragmentos compositivos, que fazem junção, montam e desmontam. Isso? Dança com sangue e raiva, com movimentos cuja gênese vem dos poros, alicerçada na indignação das desigualdades e contra os machos, tacapes, tiros, possessão, baixos salários.

Há nessa dança uma serpente, uma irrupção do demônio, do apocalíptico aflições indomáveis porque sempre na contingência da criação coletiva, daquilo que não é de um, mas de todas, das incertezas, da tensão, das fendas. Conjunto de subjetividades em cena, não dá para ficar em paz na luta que sobrepõe o estético e o político, na dança/performance (ou o que quer que seja), que luta contra o esquecimento e o silêncio. Dança feminista sem clichê composta de camadas e mais camadas de atravessamentos, ideologia, violência, memória, falas e gritos.

\section{Estética da inapropriação}

Franzoi

Pequeno manual de inapropriações 25 maio 2015, 20h, Teatro Sesc Prainha | Concepção e performer: Daiane Dordete (SC) | Sinopse: http://labperformance. wixsite.com/labperformance

Ao adentrar na sala escura o espectador se depara com uma mulher ruiva, sob um foco de luz, com vestido e echarpe verde, óculos escuros, luvas vermelhas e salto alto, com as costas na parede. Seu canto, na língua inglesa, suas poses, movimentações e interpretações vocais sensuais remetem ao estereótipo da mulher fatal, imaginário do cinema americano encarnado ao longo de décadas por Rita Hayworth, Mar- 
lene Dietrich, Ava Gardner, Marilyn Monroe, Sophia Loren, Elizabeth Taylor, Brigitte Bardot, Sharon Stone, Julia Roberts, Angelina Jolie, Monica Bellucci, Scarlett Johansson, Charlize Theron, Jennifer Lopez, Penélope Cruz e Natalie Portman. Lembranças que a atriz descontrói com ironia.

A performer cumprimenta a todos em diferentes idiomas e agradece a presença. Ao som de um hit francês, começa um strip-tease decaído, logo interrompido pela busca do roteiro. Lê o título e o prólogo com as indicações precisas quanto a drag queen que ela acaba de compor, as músicas e o desnudamento.

Ao terminar de ler as instruções, a atriz dá sequência às ações e anuncia a primeira instrução: Como não conquistar ninguém pelo estômago ou na cozinha com a tigela. Começa a preparar uma receita, apropria-se da poesia sonora, explora diferentes sons, formas e gestos, sempre se insinuando para o público e transformando-o de modo recorrente em coparticipante. Ao terminar a receita, tira as luvas e solicita pequena ajuda, pede para um espectador ler o manual enquanto ela troca de roupa. Agradece e anuncia a segunda instrução: Como não ser agradável.

A atriz assume uma persona masculinizada, pega objetos sem total consentimento, critica, assedia, menospreza, ridiculariza e incomoda. Utiliza onomatopeias e demais criações vocais. Amplifica os estereótipos do universo masculino. Para, retira o chapéu, coloca uma música de transição no celular e solicita, de novo, a uma pessoa que leia as novas instruções, agora diante de um microfone, tempo em que muda o cenário e prepara os elementos da próxima cena - microfone, tela, projetor e câmera de vídeo. A plateia fica só sob à luz da grande tela de projeção. Agradece, suspende a música e anuncia a terceira instrução: Como não prometer um discurso. Nesse momento, em frente à câmera de vídeo, a atriz projeta apenas os seus olhos enquanto lê o roteiro com o recurso de uma mesa de som, com a qual faz repetidas alterações vocais. Ao terminar, projeta outras instruções.

Sai do particular e entra no universo social no qual apresenta/discute corrupção, pedofilia, miséria, fome, saneamento básico, segurança, saúde, educação, moradia, desemprego, inflação, aborto, estupro, racismo, misoginia, burocracia, fundamentalismo, morte, sorte, passaporte, corte, assassinato, transgenia, homofobia, lesbofobia e transfobia.

Silêncio. Tanto que se ouve o som da respiração da atriz. Ao desligar o projetor, pede para levantar a tela. Começa, então, a emitir sons guturais enquanto organiza a próxima cena. Abre o baú de vime azul no qual cola duas imagens de mulheres vítimas de acoites públicos. Pega um vidro de essência, derrama uma gota na mão de cada pessoa presente e pede que aspire. Continua a pronunciar sons como se fosse um cântico de louvor. Veste um tecido branco tubular, deixa apenas pés e braços de fora. Caminha lentamente sob um corredor de luz, se ajoelha e começa a cantar o Pai Nosso como se fosse um canto gregoriano para, em seguida, contorcer no chão o corpo em poses sensuais e dramáticas. Aos poucos, lentamente se levanta e se dirige até as imagens das mulheres açoitadas. Silêncio... Deixa o tecido deslizar sobre o corpo até o chão para logo guarda-lo dentro do baú. Distribui uma folha de papel ao público.

Para a próxima instrução anuncia que precisa da ajuda de todos. Pede para fechar os olhos e lembrar de um momento da vida em que se deixa de fazer algo, ou 
deixa de ter certa atitude porque alguém julga como algo inapropriado. Alerta que não é para se preocupar, pois nada será compartilhado. Pede, também, que cada um escolha um som que represente essa memória. Convida que todos cantem seus sons e informa que será a maestrina. Para isso, combina quais os gestos que fará para conseguir reger o coral improvisado. No decorrer da ação, improvisa gesto e voz como se fosse um ritual de canto primitivo até que some na escuridão da sala. Silêncio. Ao retornar, aplaude e agradece a presença de todos.

A atriz não apresenta um final. As instruções continuam na mente dos espectadores, tal qual obra aberta que reverbera no corpo e na alma.

\section{Ritual sonoro de deusas da Itha}

Néri Pedroso

Meditação sonora $\mid 27$ maio 2015, 10h, Círculo Artístico Teodora | Concepção: Cantos de Gaia (SC) | Sinopse: http://labperformance.wixsite.com/labperformance

Dezenove pessoas entram na sala, sem sapatos. Simulacro de caverna, toda acarpetada, forte cheiro de incenso, sonorização musical suave, velas e xícaras, além de objetos, como sinos, chocalhos, tambores, tigelas, violão e gongo compõem o ambiental. Cortinas leves e cerradas conferem ao espaço uma luz azul. Quatro mulheres, as condutoras - uma em cada canto. Todas de cabelos longos e soltos, maquiadas de modo distinto com desenhos no rosto. Figurinos iguais, vestido comprido, porém de cores diferentes. Em silêncio, elas aguardam todos se acomodarem. Uma delas começa a liderar o ritual com voz envolvente.

Por orientação, a plateia se divide entre espectadores e meditadores. Oito pessoas deitam-se no centro da sala. Elas irão entregar seu corpo aos braços da mãe terra. Todos são convidados a receber a bênção dos cinco elementos da natureza, o éter, o ar, o fogo, a água e a terra. A proposta é sentir as vibrações sonoras no corpo, cada um dos participantes mentaliza o que deseja, a graça a ser recebida.

Os sons harmônicos são contagiantes, imitam os ruídos do vento, das matas, das águas, dos pássaros, do fogo. O som se amplifica, ressoa, se espalha, se esparrama sobre aqueles que meditam totalmente relaxados, imóveis, de olhos fechados. As mulheres cantam, uma delas bebe algo numa pequena xícara. Seria chá? Elas seguem uma partitura e parecem compor, em certos momentos, uma pequena orquestra. Formam um coral, cantam e assobiam.

Eu chamo o éter porque ele tem o seu poder. Eu chamo ar porque ele tem o seu poder, o ar me dá força, eu tomo o ar e recebo o seu poder. Eu chamo o fogo porque ele tem o seu poder. Eu chamo a água porque ela tem o seu poder, a água me dá força, eu tomo a água e recebo o seu poder. Eu chamo a terra porque ela tem o seu poder, a terra me dá força, eu tomo a terra e recebo o seu poder ${ }^{5}$.

Lá fora, agitados os cães latem intempestivamente, trazem resquícios de uma realidade cotidiana que se tenta neutralizar nesse ambiente, tempo e espaço. Aqui

${ }^{5}$ Falas proferidas pelas condutoras da performance ritualística. 
dentro, instrumentos percussivos simulam o som de córregos e correntezas. A voz da mulher segue. No centro da sala ninguém se mexe.

No final, o grupo de meditadores se desfaz. Todos, em círculo, são convidados a escrever algo. O silêncio é absoluto. Lá fora, os cães mais calmos deixam ouvir o barulho de uma leve chuva e o canto dos pássaros que habitam o Campeche.

\section{Corpo natureza}

Franzoi

Meditação sonora 27 maio 2015, 10h, Círculo Artístico Teodora | Concepção: Cantos de Gaia (SC) | Sinopse: http://labperformance.wixsite.com/labperformance

Um dia chuvoso, um jardim, uma casa no meio de uma vegetação essencialmente verde, uma sala e uma porta que se abre - adentra-se no espaço. Cheiro forte de incenso, tapete, almofadas e quatro mulheres, de vestidos e com o rosto pintado, uma em cada canto da sala. Pode-se optar entre ser espectador ou participante ativo. Aprofundo-me nos "cantos de gaia". Somos orientados para deitar, de forma que seja confortável, com a cabeça voltada ao centro da sala e olhos fechados. Uma voz feminina conduz aos braços da mãe terra. Sinto o cheiro da mata nas narinas, envolver o corpo que começa a relaxar a cada nova instrução. Imagens da natureza - a infância na fazenda, em Rio do Campo, se faz presente na memória, traz emoções compartiIhadas com amigos e família. O vento no varal de lençóis estendidos, a fogueira estralando e queimando a costela de chão, a água da chuva e a correnteza do rio na pele, o som de pássaros nos ouvidos e o cheiro das frutas no pomar. O corpo vibra e se recarrega energeticamente. Uma das mulheres pede para mentalizar um desejo, uma graça a ser recebida. Cada uma das mediadoras invoca o poder de um dos elementos da natureza - do éter, do ar, do fogo, da água e da terra. Respiro profundamente a cada nova voz que canta seu elemento. O copo segue totalmente relaxado e imóvel. É solicitado que cada meditador movimente lentamente seu corpo e, no seu ritmo, abra os olhos, desfaça o círculo, pegue um papel e uma caneta e escreva algo que esteja sentindo. Escrevo. Observo os outros participantes e agradeço a mãe terra. Lá fora a chuva cai.

\section{Geografia de sons desconhecidos}

Franzoi

Fogo Sonoro | 27 maio 2015, 18h, Círculo Artístico Sonoro | Concepção e performers: Isabela Irlandini e Luigi Antônio Irlandini (SC) | Sinopse: http://labperformance.wixsite.com/labperformance

Uma sala com o chão forrado com tapetes. Um homem na percussão e uma mulher no vocal, sentados cada qual em uma cadeira. O público entra e escolhe as almofadas. Um tecido cobre a mulher da cabeça aos pés, lembra burca, vestimenta xamânica ou de deuses africanos. Seu rosto e corpo não são visualizados. Inicia-se, então, um diálogo sonoro entre a percussão e a voz humana que opera de maneira 
performativa sobre as pessoas e seus territórios auditivo-visuais. Os vocalizes produzidos pela mulher não parecem vir apenas de seu aparelho vocal, mas sim de todas as partes do seu corpo, tanto internas quanto externas - caixa de ressonância que se expande no ambiente arquitetônico por meio de ondas sonoras. Os ruídos da natureza integram-se, de forma plástica, ao som produzido no interior da sala numa simbiose de acordes e vozes. Somos levados a viajar na geografia de um espaço desconhecido, visto que as pesquisas em sonoridades não têm referência antropológica ocidental. A improvisação se estende numa espécie de conversa vocal-sonora por meio de reflexões acerca dos sentidos construídos pelos músicos, suas tonadas e estilos vocais. Da mesma forma como começa, termina. (Carlos Franzoi)

\section{Mapeamento de experimentos e pequena coleção de interroga- ções}

O panorama vivenciado pela experiência estética na Semana Performática, ou seja, a arte da presença nas performances musicais, teatrais, visuais, ritualísticas e da dança, agrega um conjunto de trabalhos que podem, de modo predominante, serem pensados como obra aberta, já que suas configurações estruturais, a cada fruição do espectador, sempre se renovam como um novo objeto apresentado.

Essa poética sobre a abertura da obra de arte, pensamento de Umberto Eco (1991), no livro Obra Aberta, coloca o fruidor como cocriador, já que o artista apresenta, propõe caminhos pelos quais se pode dissecar a obra por meio de ambiguidades sígnicas. Ao fruidor, cabe mergulhar não só na emoção, mas também numa abertura intelectual que permite intervir no processo de ressignificação contínua do objeto artístico marcado pela tensão entre finitude e abertura.

Visando à ambiguidade como valor, os artistas contemporâneos voltam-se consequentemente e amiúde para os ideais de informalidade, desordem, casualidade, indeterminação dos resultados; daí por que se tentou também imposta o problema de uma dialética entre "forma" e "abertura": isto é, definir os limites dentro dos quais uma obra pode lograr o máximo de ambiguidade e depender da intervenção ativa do consumidor, sem contudo deixar de ser "obra". Entendendo-se por "obra" um objeto dotado de propriedades estruturais definidas, que permitam, mas coordenem, o revezamento das interpretações, o deslocar-se das perspectivas (Eco, 1991, p. 22).

Quando a ambiguidade da mensagem estética não determina, mas sim sugere, a obra de arte começa a ser vista como um universo de sentidos no qual o receptor passa a ser convidado a uma descoberta sensorial, de inúmeras interpretações e reinterpretações de um mesmo objeto.

Daí a possibilidade - por parte do fruidor - de escolher as próprias direções e coligações, as perspectivas privilegiadas por eleição, e de entrever, no fundo da configuração individual, as outras individuações possíveis, que se excluem mas coexistem, numa continua exclusão-implicação recíproca (Eco, 1991, p. 154).

Com forte enfoque político, o Erro Grupo tem as ruas como uma plataforma de permanente encontro com um público que abarca comerciantes, pedestres, an- 
dantes, mendigos, errantes. Muitos acabam participantes sem sequer reconhecer os mecanismos de ativação. Estão dentro sem saber direito do que se trata, poucos conhecem os termos instalação, paisagem sonora, performance, intervenção urbana, ativismo - uma potente combinação de recursos adotados pela companhia criada em 2008. Desde então, configura um conjunto de ações reveladoras de um engajamento político sem igual em outros grupos de Santa Catarina. O Erro entrelaça arte e vida, teatro e cidade, cidade e cultura. Ocupa o espaço urbano para criticar, parodiar, criar encontros e diálogos, estabelecer pausas no corre-corre diário. Radical, não assegura paz, não conforta, não dá respostas. Bem ao contrário, institui torpor e estranhamento, alcança efeitos residuais na cabeça do espectador que retorna para a casa cheio de interrogações.

Trabalho-radar, um ano após a apresentação de Sobre greens talks - segunda ação, a praça Getúlio Vargas é assumida por uma empresa da construção civil que, sob o aval público, derruba um substancial conjunto de árvores, muda todo design do espaço, cria um processo de gentrificação urbana. Por trás das melhorias, a exclusão de usuários pobres que por ali viviam.

Se a vitalidade do Erro não é a mesma a de um trabalho principiante como o de Teffa Polidoro, o certo é que ambos, por razões inversas, trazem a latência das indagações: é uma peça teatral, um ensaio aberto ou uma performance? No segundo caso, a dificuldade de enquadramento se dá possivelmente em função da alternância dos momentos de representação e apresentação. Não fica posta a presença cênica da atriz ou performer. A pesquisa da corporeidade se constitui enquanto laboratório para construção de uma personagem e de um roteiro. Segundo Teffa Polidoro "o processo da dramaturgia partiu de conversas com a avó. Minha memória seleciona o que acho importante. Crio um roteiro; depois, um roteiro de ações e busco trabalhar a distinção das presenças".

Ao buscar memórias da família sobre sua avó, Teffa entra num emaranhado de informações de espaço e de tempo. Reconstrói linearmente a história da personagem estudada, "vi toda a vida dela, o drama e tive a preocupação de não deixá-la submissa". Teffa se perde enquanto performer já que fere um dos princípios básicos da performance: o conceito de obra aberta.

Dissonância ou não da Semana Performática, o trabalho Meditação sonora destoa dos outros pelo caráter ritualístico. Terapia ou uma experiência estética? Às vezes para o espectador ou mesmo para o participante ativo não fica claro se isso é arte ou apenas uma ação de relaxamento. A atuação específica do Cantos de Gaia parece circunscrever-se, em certo sentido, no conceito mito e magia, defendido pela crítica e historiadora de arte Adalice Araújo que defende uma persistência mito mágica na arte de Santa Catarina, o telurismo da terra e a tradição mágica.

A natureza catarinense apresenta-se como um universo semântico. O artista catarinense está interligado pela experiência vivencial com a natureza, que se constitui verdadeiro universo mítico, daí a razão de acreditarmos na existência de um 'espaço catarinense' (Araújo, 1977, p.33).

Se o Erro sabe muito bem onde pisa e o que deseja, construtor de pensamentos embasados em pesquisa artística, política e filosófica, Cantos de Gaia e Due latti della 
campana transitam em práticas e interesses mais intimistas. Os trabalhos Sem cabimento e Pequeno manual de inapropriações trazem questões de gênero, o primeiro numa abordagem feminista, o segundo no universo queer. Gays, lésbicas, bissexuais, drag queem, drag king, transexuais, travestis, crossdressing, bicha, sapatão, traveco, mulher-macho, transgênero - todos termos que denotam experiências, subjetividades ou pessoas que estão fora dos padrões da heterossexualidade. Pequeno manual de inapropriações pede a coragem sugerida por Agambem (2009, p.71), quando pensa: "é o contemporâneo que fraturou as vértebras de seu tempo". Ou seja, quem quer ser contemporâneo deve fraturar a linguagem, quebrar as aparências, desunir a unidade do tempo. Nos últimos anos, em razão da amplitude de expressões de gênero, surgiu entre os estudos e ativismo trans o termo queer. Berenice Bento, estudiosa brasileira, diz que a teoria queer se organiza em eixos como:

[...] a desnaturalização das bioidentidades (coletivas ou individuais; [...] ênfase nas relações de poder para interpretar as estruturas subjetivas e objetivas da vida social; $[\ldots]$ a permanente problematização das binariedades; $[. .$.$] prioridade à di-$ mensão da agência humana; [...] crítica ao binarismo de gênero (masculino versus feminino) e sexual (heterossexual versus homossexual) (Bento, 2016, p.23).

Neste trabalho, o espectador percebe que não assiste a um espetáculo teatral clássico, mas está, sim, diante de uma experiência performática. A relação espectador-atriz, o palco cênico e o ato de representar se descontroem constantemente. Daiane Dordete apresenta personagens, situações, contextos e símbolos que tornam a obra aberta. Explora diferentes linguagens artísticas em que a linha temporal se fragmenta conforme o desenrolar do roteiro, ou melhor instruções. A atriz não desempenha apenas seu papel mas assume também o de sonoplasta, iluminadora, contrarregra, ponto, etc. Não representa personagens, mas sim personas presentes no imaginário sexual e poético social.

De modo distinto, Constelações e Entrenós discutem um paradigma vital da contemporaneidade, a relação espaço-tempo. Se Entrenós aborda a questão sob o ponto de vista quântico, articulando "a relação entre corpo-imagem, corpo-objeto e corpo-espaço", Constelações impõe a experiência real do tempo, numa ação performática que dura quase cinco horas sem intervalo. Discute o espaço e tempo de forma cronológica e recorrente por meio de um objeto que advém da cultura religiosa, o sino, que, em muitas comunidades, determina o tempo de uma série de ações ritualísticas.

Risco, esgotamento, tensão são marcas da produção poética de Franzoi vista pelo conjunto de performances apresentadas ao longo de uma carreira artística iniciada em Joinville no fim dos anos 1980 dentro da Fundação Educacional da Região de Joinville, hoje Universidade da Região de Joinville. De difícil definição até hoje, arte híbrida por essência, uma combinação de teatro, música, dança e artes visuais, a performance é a gênese da carreira em 1988, quando cursa educação artística.

A interdisciplinaridade, outro paradigma das linguagens contemporâneas, não alcança a devida potência em Fogo sonoro e Meditação sonora, que escapam do que

${ }^{6}$ Sinopse da performance. 
se entende por performance no presente trabalho. Ambos, transitam no rito e no campo musical. As nominações - fogo e meditação - são condutos que fecham as possíveis relações abertas que o espectador poderia ter em relação à obra.

Embora com dicotomias em sua curadoria, a Semana Performática cumpre uma função educativa. Bancada por três instituições, reúne importantes pesquisadores das artes da presença, oferece intercâmbio e aporte de conhecimento entre a comunidade acadêmica e não acadêmica. A iniciativa de 2015 envolveu quatro países - México, Itália, Canadá e Brasil - e de modo exemplar valorizou a produção de Santa Catarina. Elogiável também o fato da programação incorporar alunos, ex-alunos e professores, numa troca de experiências adquiridas dentro e fora do meio acadêmico. Confirma, assim, a necessidade de contínua pesquisa e renovação no campo artístico.

A curadoria acertou nos entrecruzamentos temáticos entre oficinas, jornada de pesquisa e em apresentações performáticas, cujos conteúdos dialogam no campo conceitual, estético e discursivo. Exemplo disso, é a presença do mexicano Antonio Prieto que fala sobre Políticas da identidade na performance mexicana e o trabalho Pequeno manual de inapropriações. O mesmo ocorre com as mesas-redondas Voz e(m) performance e Prática de atenção: deslocamento orientais e o trabalho Fogo sonoro, que também está em consonância com a oficina Da terra ao céu: a preparação vocal do performer. Outro imbricamento se dá entre Sem cabimento, Entrenós e Sobre greens talks - segunda ação em relação à oficina Práticas teatrais do treinamento: wiewpoints e método Suzuki.

A ser pensada a ausência de alunos, tanto da graduação e da pós-graduação dos cursos de artes visuais, dança, música e design, visto que partilham do mesmo espaço institucional. Como também da ausência de público de fora da academia. $O$ evento limita-se em si mesmo, pede melhores ferramentas de divulgação e uma avaliação corajosa capaz de ampliar suas ressonâncias.

O psicólogo e cientista político e social americano John Dewey (2010), autor do livro, Arte como Experiência, entende que a experiência resulta da interação entre algo vivo e o ambiente em que esse ser está inserido. Via de mão dupla, uma experiência não deixa ninguém imune, afeta tudo e todos.

\footnotetext{
Não há buracos [...] nem centros mortos, quando temos uma experiência singular. Há pausas, lugares de repouso, mas eles pontuam e definem a qualidade do movimento. Resumem aquilo que se passou e impedem sua dissipação e sua evaporação displicente (Dewey, 2010, p.111).
}

Entrelaçamento de instrumentalidades e realizações, para o autor a experiência constitui um todo e leva consigo sua qualidade individualizante. Orgânica, ela contagia todas as partes, querendo ou não, uma se adapta às outras e ao todo. Em fluxo, em permanente retroalimentação, essas interações integram o próprio processo de viver, ou seja, se constrói de "histórias, cada qual com seu enredo, seu início e movimento para seu fim, cada qual com seu movimento rítmico particular, cada qual com sua qualidade não repetida, que se perpassa por inteiro" (Dewey, 2010, p. 110).

A Semana Performática, de 2015, saiu do âmbito das instituições envolvidas e avançou para o centro e um dos bairros da cidade, onde alcançou outros públicos com interesses heterogêneos. Acompanhar a iniciativa, nas apresentações artísticas, 
em parte das oficinas e nas jornadas de pesquisa, alarga o conhecimento e o campo do sensível, um privilégio que, pela amplitude de suas ressonâncias, é de difícil descrição. Verdadeira partilha de saber, mas também comunhão de interrogações sobre o tempo e a arte contemporânea, os acompanhantes da agenda saem melhor instrumentalizados para prosseguir em suas pesquisas, ativados também pelo papel da arte que hoje não mais conforta, muito menos oferece o belo. Ela deve instaurar instabilidades, fissuras e reflexões sem fim.

Em se tratando do século XXI, os impasses preliminares desta narrativa que tenta ajustar o olhar de uma jornalista e de um artista, se atenuam quando ambos percebem que levantar perguntas representa uma das ferramentas de trabalho desses dois exercícios profissionais. Sem crítica não há uma obra de arte verdadeiramente contemporânea ou um jornalismo cultural cidadão. A crítica, segundo Piza (2003, p.28), é "a espinha dorsal do jornalismo cultural" e é justo nessa pratica que se dá o valor dessa experiência de entrecruzamentos de saberes. Em ações transversais, a descoberta de proximidades e distanciamentos. Na empatia (um no lugar do outro), a riqueza das revelações. Num tempo de enormes desafios, a produção de um artista ou de uma jornalista pede muito mais do que pensamento e criação. Ambos precisam articular múltiplas instâncias, adequar relações de natureza individual e coletiva. Assim o fez a Semana Performática. Assim intui-se uma possibilidade, a de caminhar juntos, desdobrar as demandas de aproximar a arte do jornalismo e o jornalismo da arte. Com isso, conquistar outros públicos.

\section{Referências}

AGAMBEM, Giorgio. O que é contemporâneo? E os outros ensaios. Chapecó: Argos, 2009.

ARAÚJO, Adalice Maria de. Mito e magia na arte catarinense. Florianópolis: IOESC, 1977.

BENTO, Berenice. Queer o quê? Ativismo e estudos transviados. Cult, São Paulo, n. 6, ano 19,2016, p. 20-24.

CHAUI, Marilena. Janela da alma, espelho do mundo. In: NOVAES, Adauto. O olhar. São Paulo: Companhias das Letras, 1988, p. 31-63.

COUTINHO, Liliana. De que falamos quando falamos de performance. Marte, n. 3, p. $8-19, \mathrm{~s} /$ ano.

DEWEY, John. Arte como experiência. São Paulo: Martins Fontes, 2010.

DERRIDA, Jacques. Pensar em não ver: escritos sobre as artes do visível. Florianópolis: UFSC, 2012.

DIDI-HUBERMAN, Georges. Sobrevivência dos vaga-lumes. Belo Horizonte: UFMG, 
2011.

ECO, Humberto. Obra Aberta. São Paulo: Editora Perspectiva, 1968.

MELIM, Regina. Performance nas artes visuais. Rio de Janeiro: Jorge Zahar, 2008.

PIZA, Daniel. Jornalismo cultural. São Paulo: Contexto, 2003.

\section{Internet}

Programa de Extensão Laboratório de Performance. Departamentos de Artes Cênicas, Centro de Artes, UDESC, Florianópolis, SC. Disponível em: http://labperformance.wixsite.com/labperformance. Acesso em: 3 abr. 2017.

Recebido em: 27/04/2016

Aprovado em: 25/06/2017 